\title{
Mind Mapping and Science Performance of Grade 5 Pupils
}

\author{
Nilda V. San Miguel \\ nildssanmiguel@gmail.com \\ Department of Education, Lumban District, Lumban, Laguna, Philippines, 4014
}

\begin{abstract}
This study aimed in determining the effect of mind mapping to the science performance of Grade 5 Pupils of San Juan Elementary School. Two strategies were executed by the researchers in order analyze the performance of 40 pupils. For the direct teaching, the teacher delivered the topic on "Female Reproductive System" with proper procedure from motivation to evaluation. Another strategy being executed by the teacher is by integrating mind mapping so as to evaluate the students' understanding using the same topic. The result of evaluation was documented. Using direct teaching using traditional strategy and through multimedia presentation, the 40 pupils obtained a mean of 2.15 and sd 1.66 in a 5 item quiz. On the other hand, peer teaching generated a mean of 3.55 and sd 1.38. Lower coefficient of variation was observed in the result of integrating mind mapping $(0.39)$ than ${ }^{\text {the }}$ result of direct teaching $(0.77)$, showing that integrating mind mapping in the teaching process generated a less varied scores than direct teaching. Using paired t-test, the tcomputed was -4.11 while the t-critical was 1.99 . These values showed that integrating mind mapping in the lesson proper has significant effect to the science performance of the pupils. The conclusion is supported by the p-value 0.00 . Based on the result of this study, recommendations to Science teachers, school heads, district supervisors and future researchers were given at the end of the study. Promotion of integrating mind mapping in teaching should be one of the foci of educators so as to improve science performance of pupils. The teacher-researchers reflected also on the importance of involving the learners on the process of teaching-learning as they themselves are the center and not the teachers.
\end{abstract}

Key words: mind mapping; Science; pupils; performance

\section{Introduction}

Education is the process of transferring knowledge to the next generation. It is also preserving information so that the future generation can still benefit from the patience and determination of the past.

This is the reason why the Department of Education (DepEd) is continually improving the curriculum. From BEC Curriculum, to RBEC, then the Understanding by Design (UBD), and the latest which is the $\mathrm{K}$ to 12 Basic Education Program.

This $\mathrm{K}$ to 12 Basic Education program came from the concept in the international scenario. There are many countries around the world, even countries from Asia, which uses this twelve year development program for the basic education, and the Philippines is already lagging behind this educational setting. Singapore has gone ahead of in such a way that they have already developed their high standard of education system. Many countries are importing their materials especially in Math and Science subjects. This country is topping in the list of quality education base from the internationally conducted contests and exams like the one being done by the Trends in Math and Science Studies (TIMSS).

But how should knowledge is transferred to students in such a way that the knowledge would be retained to them? Many studies have been conducted to investigate on the effectiveness of different strategies like cognitive approach, deductive approach, inductive approach, spoon-feeding approach, peer-tutoring, group activity, simulation, and many other means of instructing. 
When it comes to Science subject, what would be an effective way so that students would easily grasp the concepts and connected ideas to a certain topic? This is the focus of this study.

\subsection{Background of the Study}

The San Juan Elementary School started as an Annex to Bubukal Elementary School. It has been operating since 2006. The third batch of grade five has completed the course requirement from the Department of Education last school year 2016-2017. After the recognition ceremony, the Parents-Teachers Association pushed through its independency from Bubukal Elementary School and the local government granted the autonomy through the able leadership of Dr. Myra D. Collado.

There are 40 grade five students and their Science subject is being handled by the researcher of this study. The topics in this subject follow the topics as line-up by DepEd under the K to 12 program. It includes the system of the human bodies, taking care of health, healthy foods, the ecosystem, plants and animals, our environment, and the universe.

To learn these topics, the teacher implements many strategies: experimentation, group activities, lecture method, exploratory activity, multimedia presentation, and integration of mind mapping.

How is the mind mapping learning style in terms of the output in the exams and quizzes of these grade five students? Are they learning much in the same level or degree that they learn using the lecture type method or the typical visual aid method? These are the questions that the researcher has in mind in the beginning of the study.

\subsection{Theoretical Framework}

The concept of learning through mind mapping was developed by Tony Buzan, a British popular psychologist in 1971. He promoted the use of diagrams that visually "map" information using branching and radial maps. He also followed the concept of David Ausubel who said that learning takes place when a person begins with what he knows and relates present experiences to what is already attained before. This notion comes from the constructivist approach which proposes that learning can be constructed in the mind of the learners.

Furthermore, the mind mapping method can be characterised as an organisation and structuring strategy. Pieces of information will be structured netlike, corresponding to the way the memory stores information. From the perspective of developmental psychology the quality of order formation; assigning features and relations to concepts and events depends on the cognitive stage of development of each child. This leads in the highest phase to categorical groupings, in which abstract superordinate concepts will be applied (Grünke \& Stemmler 2004, 259f.).

\subsection{Conceptual Framework}

The figure shows the conceptual model of this study.

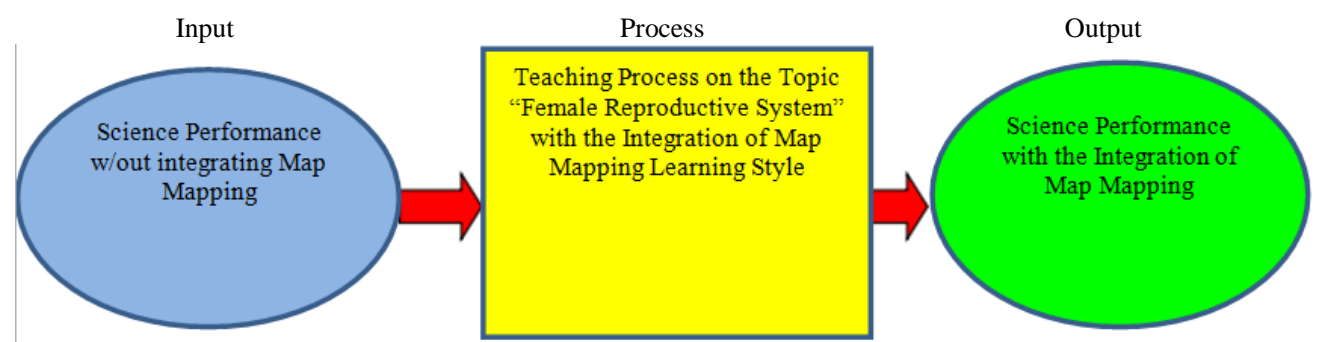

Fig. 1. The paradigm 
The input shows Science Performance without integrating Map Mapping learning style. For the Process, the researcher integrated Map Mapping learning style during teaching-learning process. And for the output, the teacher gave a 5-item word problem quiz and recorded the result of the learners' performance.

\subsection{Statement of the Problem}

This study will aim to determine if the integrating mind mapping learning style will increase the academic performance of Grade 5 learners in San Juan Elementary School.

Specifically, it seeks to answer the following question.

1.) What is the mean level of academic performance of Grade 5 learners of San Juan Elementary School in Science not applying mind mapping learning style?

2.) What is the mean level of academic performance of Grade 5 learners of San Juan Elementary School in Science integrating mind mapping learning style?

3.) Is there a significant difference between the academic performance of learners not integrating and integrating mind mapping learning style?

\subsection{Scope and Limitations}

This study was conducted in the first quarter of the school year 2017-2018, that is, from June to August of 2017 using the learners of Grade 5-Capricorn in Science which is one of the major core subjects in the K-12 Basic Education Program. Forty students became the focus of this study.

\section{Review of Related Literature}

A mind map is a diagram used to visually organize information. It is hierarchal and shows relationships among pieces of the whole. It is also often created around a single concept, drawn as image in the center of a blank page, to which associated representations of ideas such as images, words and parts of words are added. Major ideas are connected directly to the central concept.

Mind Mapping allow students to express their thoughts and ideas non-linguistically, instructors actually see the graphic representation of a student's thought process (Holzman, 2004). Mind Mapping differ from graphic organizers because they are used to promote "more strategic thinking" and encourage students to focus on the processes used to produce the "correct" answer (Holzman, 2004). By coaching students to correctly use the Mind Mapping in their daily lessons, students will have a greater sense of control of the way they handle classroom material and provide a strategy for organization that will allow them to form meaningful connections with the content. This reading gives us how and why mind mapping gives understanding to the readers about present study.

The need for this unique method can be traced from the one who popularize this. Joseph D. Novak together with his research team at Cornell University developed this in the 1970s "as a means of representing the emerging science knowledge of students." (Novak, 2008) This is showing us that because knowledge is rapidly being developed in today's modern times, a way of connecting ideas in a meaningful way should be developed to aid people in easily understanding newly developed concepts, and will make them relate to it easily.

A study by Al-Jarf (2009) confirms that Mind Mapping software offers a powerful approach for improving the ability of anyone to generate, visualize and organize ideas. The subjects taking part in the study reported that the Mind Mapping tool encouraged creative thinking and they became faster at generating and organizing ideas for their writing. 
Researches show that mind mapping learning style is useful and has many benefits for students and teachers. Goodnough and Woods (2002) discovered that partakers in their study perceived Mind Mapping as a fun, interesting and motivating approach to learning. Several of these participants attributed the fun aspect to the opportunity to be creative when creating Mind Maps through lots of choice in color, symbols, key words and design.

Mind Mapping provides an effective approach for promoting better understanding in learning and training. Its flexibility also means that it possesses several uses when teaching. Using Mind Mapping for lesson planning can help teachers or trainers identify a logical plan or teaching route and increases recall of the subject matter. This can boost teaching confidence and facilitate the smooth running of programmes. Boyson (2009).

\section{Research Design and Methodology}

\subsection{Research Design}

The study adopted in this research is experimental design. According to Blay (2013), this design is used when a researcher would like to find out the effectiveness of one factor towards the change of behaviour to another factor. In this study, the researcher made use of mind mapping to find out if there will be a significant change in academic performance of grade 5 pupils.

\subsection{Population}

The population for this study is the grade 5 learners of San Juan Elementary School, school year 2017-2018. The sections and frequency is presented in the table below.

Table 1. The student participants

\begin{tabular}{|c|c|}
\hline Section & Number of Learners \\
\hline Male & 19 \\
\hline Female & 21 \\
\hline Total & $\mathbf{4 0}$ \\
\hline
\end{tabular}

\subsection{Data Gathering Procedure}

Data and results were gathered and analyzed using the following steps undertaken by the teacherresearcher (shown in next page).

Mean and standard deviation were used to analyze the data gathered from series of quizzes with and without the intervention of Mind Mapping learning style. For the significant difference between the two arrays of data, t-test for independent samples was used. 
Administration of Quiz

without Peer Mind Mapping style

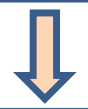

Administration of Quiz with the

Integration of Mind Mapping learning style

Observation of Significant Difference

in the Results of Two Sets of Data

Fig. 2. The flowchart of procedures undertaken

\section{Presentation, Interpretation and Analysis of Data}

The table shows the result of the of a 5-item word problem quiz given to grade 5 learners of San Juan Elementary School.

Table 2. T-test showing significant difference in means

\begin{tabular}{|c|c|c|c|c|c|c|c|}
\hline Teaching Process & $\mathbf{n}$ & Mean & SD & T-critical & T-computed & P-value & Decision \\
\hline $\begin{array}{c}\text { Without Peer } \\
\text { Teaching learning } \\
\text { style }\end{array}$ & 40 & 2.15 & 1.66 & & & & \\
$\begin{array}{c}\text { With Peer } \\
\text { Teaching learning } \\
\text { style }\end{array}$ & 40 & 3.56 & 1.38 & & & & \\
\end{tabular}

alpha $=0.05$

The two teaching processes being compared are classroom sessions without the integration of mind mapping learning style and classroom sessions with the integration of mind mapping learning style. Without the integration of mind mapping style, the learners got a mean of 2.15 and an SD of 1.66 out of a 5item word problem quiz on the topic of "Female Reproductive System". On the other hand, with the integration of mind mapping learning style, the learners' mean is 3.56 and SD is 1.38. This shows that learners did better in the teaching-learning process when mind mapping learning style was integrated to learn concepts and skill in Science. Using paired t-test, the T-critical is 1.99 while the T-computed is 4.11. Since the absolute value of the T-computed is greater than the T-critical, it can be said that there is a significant difference between the two means. The P-value 0.00 which is lower than the alpha 0.05 supports the claim that there is a significant difference between the scores in quiz without the integration of mind mapping 
learning style and with the integration of mind mapping learning style, thus, the implication that the teaching process affects the Science performance of grade 5 learners. When integration of mind mapping learning style is used alongside teaching and learning, higher Science performance is exhibited by the learners compare with the teaching process without the integration of mind mapping learning style. These findings reveal that mind mapping of great value to the teaching of science. This is in agreement with Toi (2009) shows that Mind Mapping can help children recall words more effectively than using lists, with improvements in memory of up to $32 \%$.

\section{Recommendations}

Considering the result obtained from this study, the following recommendations are given to target persons:

- That Science Teachers make use of mind mapping more than traditional outlining. Though this would take more effort to do, it would give better academic achievement for pupils;

- That Science Coordinators update Science Teachers on the how-and-why of mind mapping so that Science Teachers would be more effective in using that teaching tool;

- That School Heads continue to promote the use of mind mapping not only for Science subject but to all subjects (if applicable);

- That the Department Education (on district or division level) raise concerns, seminars and workshops on the effective use of mind mapping so that educational status can be sustained or even attain higher heights.

\section{References}

Al-Jarf, R. (2009), 'Enhancing Freshman students' Writing Skills with a Mind Mapping software'. Paper presented at the 5th International Scientific Conference, eLearning and Software for Education, Bucharest.

Blay, B. E. (2013). Elementary Statistics. Anvil Publishing, Inc.

Boyson, G. (2009), 'The Use of Mind Mapping in Teaching and Learning'. The Learning Institute, Assignment 3.

Buzan, T. and Buzan, B. (1994), The mind map book: How to use radiant thinking to maximize your brains untapped potential. Dutton.

Goodnough, K. and Woods, R. (2002), 'Student and Teacher Perceptions of Mind Mapping: A Middle School Case Study'. Paper presented at the Annual Meeting of American Educational Research Association, New Orleans.

Grünke, M./ Stemmler, M. (2004): Förderung begrifflich-kategorialer Verarbeitung. In: Lauth, G./ Grünke, M./ Brunstein, J. (Hrsg.): Interventionen bei Lernstörungen. Förderung, Training und Therapie in der Praxis. Göttingen: Hogrefe, S. 258-267

Holzman, Stefanie (2004). Thinking maps: Strategy-Based Learning for English Language Learners (and Others). Presented at the 13th Annual Administrator Conference.

Novak, J. D. and Cañas, A. J. (2006). "The Theory Underlying Concept Maps and How To Construct and Use Them", Institute for Human and Machine Cognition.

Toi, H (2009), 'Research on how Mind Map improves Memory'. Paper presented at the International Conference on Thinking, Kuala Lumpur.

https://en.wikipedia.org/wiki/Mind_map 